\title{
V. Bucciantini
}

ORCID: 0000-0001-6709-4222

veronica.bucciantini@unifi.it

Флорентийский университет

(Италия, Флорениия)

\section{Fragments of THE historians of Alexander the Great in the Naturalis Historia: BetWeEn MeMORY AND OBLIVION}

Аннотация. В статье анализируется VI книга «Естественной истории» Плиния Старшего, содержащая сведения историков Александра Великого и других участников восточного похода. Плиний, обнаруживая знакомство со свидетельствами бематистов, не привлекает сочинение Аристобула по исторической географии, а Птолемея упоминает лишь в отдельных местах в связи с незначительными ссылками. Более того, часть приводимых им сведений заимствована из произведений Юбы II. Таким образом, при изложении рассматриваемых в статье фррагментов Плиний вдохновлялся содержанием текстов Неарха. Помимо всего, кратко оценивая свидетельства современниковочевидцев, историков Александра Великого, Плиний не отмечает важности их информации. Сведения историков Александра Великого, использованные в «Естественной истории», отнюдь не играют столь решающей роли, как в «Анабасисе» (или «Походе Александра») Арриана из вифинской Никомедии. Историк Арриан полагал, что достижения Александра Великого следует использовать в качестве "примера» для императора Траяна (ср. «Деяния божественного Августа»), в то время как Плиний не ставил целью, да и не мог «подать пример» императору Веспасиану или его соправителю Титу. В современной Плинию политической жизни занятие историографией не являлось своего рода «бегством от действительности» (иными словами, это вовсе не приветствовалось), особенно в последние годы правления Нерона. Энциклопедическая направленность труда Плиния была обусловлена его содержанием: «описание мира в эпоху Флавиев» более не вызывало интереса и отнюдь не вдохновлялось мифом об Александре Великом - его место занимает Imitatio Alexandri в августовской пропаганде.

Ключевые слова: фррагменты историков Александра Великого, VI книга «Естественной истории», Юба II, Аристобул, Птолемей, Неарх, «Анабасис» Арриана 
Для иитирования: Bucciantini V. Fragments of the historians of Alexander the Great in the Naturalis Historia: Between memory and oblivion // Шаги/Steps. T. 6. № 1. 2020. C. 26-39. DOI: 10.22394/2412-9410-2020-6-1-26-39.

Статья поступила в редакиию 9 октября 2019 г.

Принято к печати 14 декабря 2019 г.

Shagi / Steps. Vol. 6. No. 1. 2020

Articles

\title{
V. Bucciantini
}

ORCID: 0000-0001-6709-4222

veronica.bucciantini@unifi.it

University of Florence

(Italy, Florence)

\section{Fragments of the historians of Alexander the Great in the Naturalis Historia: BETWEEN MEMORY AND OBLIVION}

\begin{abstract}
The analysis starts from the $6^{\text {th }}$ Book of the Naturalis Historia, where we can find information derived from the historians of Alexander and those others scientists who followed his expedition. Pliny thus proves to know the work of the bematists but doesn't consider at all the historiographical work of Aristobulus, and mentions Ptolemaeus only in specific dossiers regarding certain subjects. Moreover, the Naturalist declares that he drew his account from Juba II, but in terms of the passages analyzed here he consistently took inspiration from the work of Nearchus. However, Pliny made only sporadic notes about the contemporary historians of Alexander and he did not consider their importance. The passages concerning Alexander's historians in $\mathrm{NH}$ don't have the kind of significant role as they will have in Arrian's Anabasis: the historian from Nicomedia thinks that the achievements of Alexander the Great as Res Gestae should be used as exemplum for Trajan, while Pliny doesn't want and cannot "show as exemplum" anything to emperors Vespasian or Titus. In the contemporary political life of the Plinian age, historiography was not a very neutral refuge (in other words it wasn't something very advisable to do), especially during the last years of Nero's empire. The encyclopedic purpose of the work has strongly conditioned the content: the author of "the inventory of the World of the Flavian age" was no longer interested and fascinated by the myth of Alexander, which had been the reference point of the Imitatio Alexandri of Augustan propaganda.
\end{abstract}

Keywords: Fragmentary historians of Alexander, Book 6 of $\mathrm{NH}$, Juba II, Aristobulus, Ptolemaeus, Nearchus, Arrian's Anabasis. 
To cite this article: Bucciantini, V. (2020). Fragments of the historians of Alexander the Great in the Naturalis Historia: Between memory and oblivion. Shagi / Steps, 6(1), 26-39. DOI: 10.22394/2412-9410-2020-6-1-26-39.

Received October 9, 2019

Accepted December 14, 2019

$\mathrm{I}$

$\mathrm{n}$ the $1^{\text {st }}$ Book of Naturalis Historia, Pliny offers not only a list of all the topics he intends to address in the following 36 books, but also the sources of these arguments, dividing them between Roman and external - ex auctoribus romanis ed (ex auctoribus) externis. The clarity and precision of the Plinian scheme did not prevent the birth of a debated Quellenforschung ${ }^{1}$ with regard both to the content and sequence of the Indices and to the text of the $\mathrm{NH}$.

I do not intend to go into any of the much debated Plinian problems, such as the importance of intermediate sources, neither the more or less relevant influence of the Catonian model on Plinian encyclopedias ${ }^{2}$, nor the discussion of the antiHellenism of the $N H$.

I just want to suggest some observations on the traces that can be found, regarding the fragments of the historians of Alexander, first of all on the Book 6 and then also on the entire work, defined by Gian Biagio Conte as "the inventory of Plinian World" [Conte 1982: xvii].

The analysis starts from the Book 6 because it closes the section of the studies dedicated to geography, and treats the Asian regions, i. e. Central and Eastern Asia, India, Parthia, Mesopotamia and Arabia. The Indian section (6.56-91) contains information derived from the historians of Alexander and those others scientists who followed the expedition: there are numerous Greek sources as compared to Latin ones, even if it is not certain that Pliny directly gathered these from the quoted authors.

The Naturalist often intervenes with updates dated back to his time: e. g. Plin. $\mathrm{NH} 6.84^{3}$, which is related to the activity of Annius Plocamus ${ }^{4}$ attested by a bilingual inscription of 5-6 CE found not far from Berenice on the Red Sea 5 .

${ }^{1}$ Brunn [1856] believed that the Indices were a faithful list of the sequence of authors used by Pliny; Münzer [1897] focused on the historical and antiquarian sections but he did not reach convincing conclusions, hypothesizing also primary sources and intermediate sources such as Varro and Verrius Flaccus, whose importance was later supported by Rabenhorst [1907]. Klotz [1906; 1907], studying in particular Plinian geography, attributed the errors to the manuscript tradition, while Detlefsen [1909] considered that Pliny used a number of works inferior to those declared in the Indices. Della Corte [1954] then hypothesized a substantial Varronian influence on Pliny; this problematic relationship was also discussed by Sallmann [1971], which still remains a point of reference in the history of studies. The largest Plinian bibliography until 1946 is in [Le Bonniec 1946]. See also [Brieger 1857; Aly 1882; Dalstein 1885; Stadler 1891].

${ }^{2}$ See [Della Corte 1954; Cotta Ramusino 2004: 52-53].

${ }^{3}$ 6.84: Nobis diligentior notitia Claudi principatu contigit legatis etiam ex ea insula advectis. id accidit hoc modo. Anni Plocami, qui mar is Rubri vectigal a fisco redemerat, libertus circa Arabiam navigans aquilonibus raptus praeter Carmaniam, XV die Hippuros portum eius invectus, hospitali regis clementia sex mensum tempore inbutus adloquio percunctanti postea narravit Romanos et Caesarem. I adopt in this paper the Latin text after Mayhoff.

${ }^{4}$ See [Meredith 1953; De Romanis 1992; Janni 2004: 125-126].

${ }^{5}$ We should note the importance of the impulse given by emperor Nero to the geographical explorations, with expeditions to Ethiopia looking for the sources of the Nile. and towards 
It is essential to evaluate the quality of Plinian information and the role played by Juba II in relation to the testimonies of the historians of Alexander. I will begin the analysis with the fragments of the bematists reported by Pliny: these were participants in the expedition of Alexander the Great in Asia who were responsible for measuring the distances travelled, and their collected data was added to the Royal Archive in Babylon after the death of the Macedonian king ${ }^{6}$. The bematists, whose fragments we retain, are Baeton ${ }^{7}$, Diognetus ${ }^{8}$, Amyntas $^{9}$, Philonides of Crete ${ }^{10}$ and Archelaus ${ }^{11}$, but Pliny mentions only the first two. Diognetus is quoted three times in the Indices (6.12.13) and only once in the text, together with Baeton, in relation to the distance from the Caspian Gates to the city of Hekatompylon (6.45). Baeton is quoted also in the text at 6.69, where Pliny describes an Indian phenomenon occurring in the Monaedi and Suari region and, more precisely, on Mount Maleus: here the shadows project to the north for six months in winter, and to the south for six months in summer. Pliny alludes to this event also in 2.184 talking about the Oretes Indians, and he notes that it can occur only on a mountain located on the equator [Schiwek 1962: 42-43; Janni 1978: 95-96]. What is interesting here is not only that the bematists reported information in addition to the distances travelled, but also that these extreme various reports came to Pliny, or more likely to the intermediate source that the Naturalist used. The last Plinian fragment of Baeton derives from the $7^{\text {th }}$ Book, the first one dedicated to animals: actually it represents a book on its own, for the enormous variety of anecdotes, which the Naturalist probably derived from collections of exempla and mirabilia ${ }^{12}$. In this text Pliny treats the tribes of Scythians Anthropophagi, and Baeton adds that these wild men, with the soles of their feet pointing backwards, were wandering like nomads with beasts and that they could not live in a different climate ${ }^{13}$. Also in this case Baeton - defined as itinerum mensor - wrote a report that, in addition to data about distances, also contained a

the Caspian Gates, the Silk Road, the Baltic Sea and the Amber Way. The Roman expeditions are located from 62 to $67 \mathrm{CE}$ : on one hand, they went up to the Nile towards equatorial Africa, on the other hand they tried to know and to control the caravan routes through the desert, because these linked the Persian Gulf and the Mediterranean. See [Kirwan 1957; Cotta Ramosino 2001: 222-223].

${ }^{6}$ We know their works from some passages of Strabo: at 15.1.11 C689 for the measure of the shortest side of India the Geographer refers 16.000 stadia, a measure that Eratosthenes had obtained from the records of the stages. In another passage (15.2.8-9 C723-724) Strabo mentions the width of the Ariana, that could be calculated either from the Caspian Gates to Alexandria Ariana or from the region of Ariana to the south towards the Drangiana and up to the Indus:

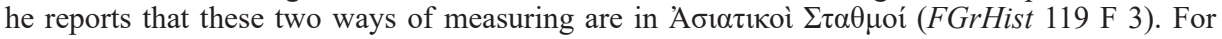
bematists see [Schwartz 1897; Matthews 1974; Tzifopoulos 2013].

${ }^{7}$ See [Schwartz 1896: 2779]; FGrHist 119; BNJ 119.

${ }^{8}$ See [Berger 1903: 785]; FGrHist 120; FGrHist 2016; BNJ 120.

${ }^{9}$ FGrHist 121; BNJ 121 .

${ }^{10}$ FGrHist 122; BNJ 122; [Tzifopoulos 1998: 137-170].

${ }^{11}$ FGrHist $123 ;$ BNJ 123.

12 7.11: super alios autem Anthropophagos Scythas in quadam convalle magna Imavi montis regio est quae vocatur Abarimon, in qua silvestres vivunt homines aversis post crura plantis, eximiae velocitatis, passim cum feris vagantes. hos in alio non spirare caelo ideoque ad finitimos reges non pertrahi neque ad Alexandrum Magnum pertractos Baeton itinerum eius mensor prodidit.

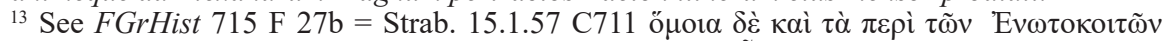

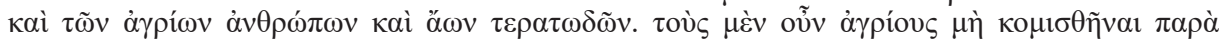

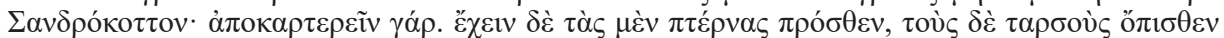

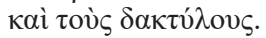


lot more information on the movements of the sun and stars and on the populations of "others" encountered during the expedition.

The problem of the transmission of the data collected by the bematists to Pliny, and probably of the non-direct access to these texts by the Naturalist, also seriously impacts the historians of Alexander. Ptolemaeus and Aristobulus are also the main sources of Arrian's Anabasis ${ }^{14}$, as can be seen from the beginning of the first book ${ }^{15}$. The historian of Nicomedia did not always use first-hand sources but also relied on compilations of selected sources; what is interesting to me, in this case, is that he favored these above the just mentioned generals of Alexander ${ }^{16}$. Aristobulus of Cassandrea ${ }^{17}$ probably had only a technical role in the Asiatic expedition, and an interest in engineering works and in the strategic aspect linked to the use of natural elements. We don't know the title or the internal subdivision of his work, probably published in his old age, but it likely privileged those elements that supported the strategic choices of the sovereign and that had determined military success.

The Aristobulean fragments contain a great variety of themes and interests, such as geography, ethnography, location names, botany and hydrography: it should be noted, however, that the work is cited only by Greek authors, such as Strabo ${ }^{18}$, Plu$\operatorname{tarch}^{19}$ and Atheneus ${ }^{20}$. Some studies [Moretti 2012; 2013] have highlighted points of contact and correspondence between the Aristobulean fragments and some passages of the Historiae Alexandri Magni of Curtius Rufus, thus allowing us to hypothesize that the information derived from the Aristobulean work was circulated, perhaps summarized, or was present in other intermediate sources.

However, the fact remains that neither in the Indices, nor in Pliny's work, nor in any other Latin work is there mention of the historian of Cassandrea.

Instead, there are several testimonies in the Naturalis Historia about Ptolemae$u^{21}$ : he descended from a lateral branch of the Macedonian royal family, and was among the Hetairoi exiled by Philip II in 337 BCE.

Ptolemaeus later became one of the king's bodyguards and, after the death of Alexander, Basileus of Egypt in $305 \mathrm{BCE}$, and he wrote - probably at an advanced age - an Alexandergeschichte. Unlike Aristobulus, Ptolemaeus, according to the fragments we have, described in detail various military operations of Alexander's

${ }^{14}$ See [Bosworth 1980: 16-34; Tonnet 1988 (1): 105-219; Sisti 2001: 301-302].

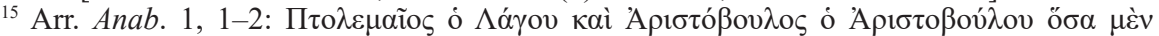

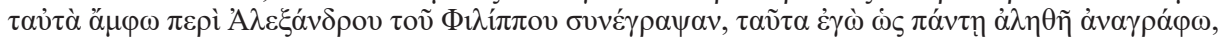

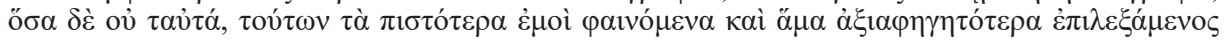

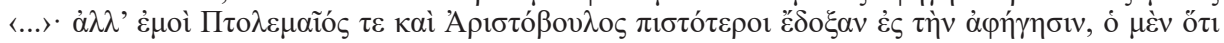

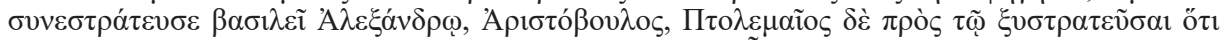

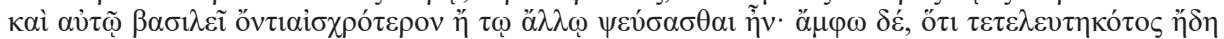

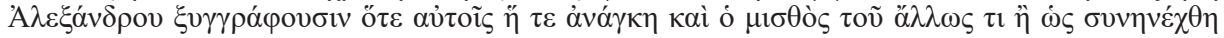

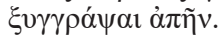

${ }^{16}$ Arrian adds (Anab. 1.3) that he used even information of other writers who were not "entirely incredible". About this "secondary" tradition see [Bosworth 1988: 61-93].

${ }^{17}$ FGrHist 139; [Berve 1926: 64-66, n. 121; Pearson 1952; 1960: 150-187; Brunt 1974: 65-69; Pédech 1984: 331-405; Sisti 2001: xxix (with huge bibliography); Heckel 2006: 46].

${ }^{18}$ For 15 times: FF 9b, 19, 20, 28a, 35, 36, 37, 38, 39, 41, 42, 48, 49b, 51b, 56, 57.

${ }^{19}$ For 11 times: T 2; FF 2, 3, 4, 5, 7b, 11, 21a, 46, 59, 63.

${ }^{20}$ For 5 times: FF 6, 9a, 18, 32, 47. Moreover Aristobulus is also mentioned twice in Luciano, see TT 3, 4 and once in Menander, see T 5.

${ }^{21}$ FGrHist 138; BNJ 138; [Berve 1926: 329-335; Wirth 1959; Pearson 1960: 188-211; Worthington 2016; Howe 2018]. 
expedition (attacks, sieges, fights and conquests of new territories) but he rarely adds geographical data, as Arrian (e. g. Anab. 5.20.8) points out. In the Plinian work the references to Ptolemaeus appear in the Indices of Book $12^{22}$, dedicated to botany (de arborum natura), and of Book 13, dedicated to the most particular tree species (de perigrinis arboribus). It is also noteworthy that these two Indices are identical and are the only two Testimonia cited by Felix Jacoby [1926-1930; 1930] in the collection of Fragments (FGrHist 138).

But there are also other references to Ptolemaeus: two passages come from the Book 7, which reports on the Exempla Mirabilia. At 7.207-208 ${ }^{23}$ Pliny describes the dawn of navigation with the evolution of ships and reports that, according to Mnesigiton, it was Alexander the Great who introduced ships up to 10 orders of oars, while Ptolemaeus Soter introduced the twelve orders of oars, according to Philostephanus. Then follows an unlikely and impossible size of ships of thirty and forty orders of oars at the time of Ptolemaeus Philadelphus and Ptolemaeus Philopator. I am not going to talk about the analysis of the text, which represents an important source for the history of the ancient navigation, as Janni [1996: 245-250] clearly analyzed, but I am interested in underlining two points:

1) Ptolemaeus Soter is called the Savior of Egypt, and this title fits in a context of royal succession in chronological order, from Alexander the Great until Ptolemaeus Philopator;

2) Philostephanus, who, according to Pliny, could have reported the news was a pupil of Callimachus of Cyrene in Alexandria. During the reign of Ptolemaeus Philopator he wrote a history of Cyprus, now lost. This probably suggests an Egyptian context for the origin of information and perhaps also for the intermediate source, which I think may be Juba II. Again, in the Book 7 of the NH 7.123-12424 there is a list of scholars who distinguished themselves in different sciences: Berossus $^{25}$ in astrology, Apollodorus in grammar and Hippocrates and others in medical science.

Pliny later adds that during the sacred Megalesia festival Cleombrotus of Kea was rewarded with 100 talents by King Ptolemaeus for saving the life of King Antio-

22 Index EXTERNIS Liber 12 Theophrasto. Herodoto. Callisthene. Isigono. Clitarcho. Anaximene. Duride. Nearcho. Onesicrito. Polyclito. Olympiodoro. Diogneto. Nicobule. Anticlide. Charete Mytilenaeo. Menaechmo. Dorotheo Athenaeo. Lyco. Antaeo. Ephippo. Dinone. Adimanto. Ptolemaeo Lagi.

23 7.207-208: nave Iasonem primum navigasse Philostephanus auctor est, Hegesias Parhalum, Ctesias Samiramin, Archemachus Aegaeonem, biremem Damastes Erythraeos fecisse, triremem Thucydides Aminoclen Corinthium, quadriremem Aristoteles Carthaginienses, quinqueremem $<M>$ nesi $<$ gi $>$ ton Salaminios, sex ordinum $<X>$ enagoras Syracusios, $a b$ ea ad decemremem $<M>$ nesigiton Alexandrum Magnum, ad duodecim ordines Philostephanus Ptolemaeum Soterem, ad quindecim Demetrium Antigoni, ad XXX Ptolemaeum Philadelphum, ad XL Ptolemaeum Philopatorem, qui Tryphon cognominatus est.

24 7.123-124: Hippocrates medicina, qui venientem ab Illyriis pestilentiam praedixit discipulosque ad auxiliandum circa urbes dimisit, quod ob meritum honores illi quos Herculi decrevit Graecia. eandem scientiam in Cleombroto Ceo Ptolemaeus rex Megalensibus sacris donavit centum talentis servato Antiocho rege. magna et Critob $<u>$ lo fama est extracta Philippi regis oculo sagitta et citra deformitatem oris curata orbitate luminis, summa autem Asclepiadi Prusiensi condita nova secta, spretis legatis et pollicitationibus Mithridatis regis, reperta ratione qua vinum aegris medetur, relato e funere homine et conservato, sed maxime sponsione facta.

${ }^{25}$ See [Primo 2009: 65-72] with bibliography. 
chus. Cleombrotus, father of Erasistratus and Cleophanus, was the private physician of Seleucus Nicator and, since he had to move away from Antigonus Monophthalmus after $316 \mathrm{BCE}$, he escaped to Egypt. It may be thought that the Rex Ptolomaeus of the Plinian passage that rewarded the physician of Kea for saving the life of Antiochus, son of Seleucus I, is in fact Ptolemaeus Soter. This reference, if considered correct, would refer to information concerning the kingdom of Ptolemaeus the First and not his participation in the expedition of Alexander. Such an interpretation is supported by a passage concerning painting ${ }^{26}$ in Book 35, where Pliny, describing the extraordinary ability of Apelles to make portraits that were so close to the original, remembers that this artist didn't have good relations with Ptolemaeus the First, whose official painter at court was Antiphilus. The Naturalist adds that Apelles once arrived in Alexandria due to a violent storm, and was invited to court by a jester who had been bribed by the rivals of the famous painter. King Ptolemaeus came to know about the deception and asked Apelles to draw the servants who organized this; the painter did it so well that the malefactor was recognized. In the Plinian account Ptolemaeus is defined as being part of the entourage of the Macedonian King - in comitatu Alexandri - and reigning in Alexandria - regnante Alexandriam. These observations help to place the terminus post quem in 305 for this episode. Even the story of Apelles, therefore, refers to information involving the reign of Ptolemaeus, as do the other two previously mentioned Plinian testimonies .

What has been analyzed until now demonstrates that in Pliny's work there is no trace of the historiographical fragmentary work of Aristobulus and Ptolemaeus, which has come down to us, although their work is the point of reference for Arrian's Anabasis.

In fact, the first of these authors is never mentioned in the $N H$, and the second one is found in some passages regarding events that occurred after $305 \mathrm{BCE}$, once he had become King of Egypt.

In the mentioned texts, there are probably specific dossiers on navigation, on scholars, on painting, produced perhaps in an Alexandrian environment and consulted by Pliny: it is also possible to exclude the direct use by the Naturalist of the literary work of Ptolemaeus.

I shall now focus on the fragments of Nearchus of Crete and Onesicritus of Astypalea. Some scholars ([Sprengler 1891]; see [Sallmann 1971: 86, n. 100]) agree that Pliny knew Onesicritus' works through the filter of Juba II of Mauretania ${ }^{27}$ as reported by the Naturalist at 6.96: sed priusquam generatim haec persequamur indicari convenit quae prodidit Onesicritus class Alexandri circumvectus in mediterranea Persidis ex India, enarrata proxime a Iuba, deinde eam navigationem quae his annis comperta servatur.

On the other hand, the analysis of the Nearchean fragments in Pliny's work is based on three quotations in the Indices (6.12.13), and three of the five references

${ }^{26}$ 35.89: non fuerat ei gratia in comitatu Alexandri cum Ptolemaeo, quo regnante Alexandriam vi tempestatis expulsus, subornato fraude aemulorum plano regio invitatus, ad cenam venit indignantique Ptolemaeo et vocatores suos ostendenti, ut diceret, a quo eorum invitatus esset, arrepto carbone extincto e foculo imaginem in pariete delineavit, adgnoscente voltum plani rege inchoatum protinus.

${ }^{27}$ FGrHist 275; [Roller 2003]. See for a complete Quellenanalyse [Sallmann 1971: 35-119]. 
in Book Six simultaneously cite the two admirals. I would like to start with the passages where the Cretan is quoted alone: at $6.97^{28}$ it is the oppidum of Arbis ${ }^{29}$ founded by Nearchus on the homonymous river, as we also read in Arr. Ind. 22.8. Pliny probably confused the natural port at the mouth of the Arabis, which is located after the mouth of the Indus, with a city of the same name, but what is interesting to us is that the city was founded by Nearchus and probably the information comes from the Cretan.

The admiral is also cited at $6.107^{30}$ - Nearchus scripsit - in connection with the length of the coast of Carmania which is calculated as 1.250 Roman miles, probably corresponding to 10.000 Greek stadia. According to Strabo (15.2.1 C720), it is clear that Carmania is 3.700 stadia, a number that, added to the length of the coast of the Ichtyophagi (7.400), amount to 10.000 stadia.

Apart from these considerations on the measurements [Brunt 1983: 523-525; Bucciantini 2013], it appears that the information was not gathered directly from Nearchus' report, but more probably from its synthesis: was not Onesicritus interested in naming the city founded by the rival to the expedition's command? In the other three passages the Admiral is quoted together with Onesicritus. The first $(6.96)^{31}$ presents a textual problem related to nec nomina habet mansionum nec spatia, which was integrated by Geier [1844] with omnia, possibly mistakenly left out by the copyist - propter similitudinem antecedentis vocis. The reports of navigation had to have many names and measurements of places and the corrupted text is very difficult to understand: Pliny had to know nomina mansionum et spatia, even though he had not drawn directly from his sources [Brown 1949: 105-109].

The two marshals of the expedition sent by Alexander are also cited in two other passages of the Book $6\left(109^{32}\right.$ and $\left.124^{33}\right)$ : in the first we learn that Onesicritus and Nearchus calculated 1,700 miles from the mouth of the Indus to the Persian Gulf, and from there to the swampland formed at the Euphrates; this measurement is much lower than the 23,000 stadia handed down in Arrian [Bucciantini 2015: 72-77].

In the second passage, on the other hand, a much shorter partial measurement, which is the length of the navigable tract of the Euphrates from Babylon to the Persian Gulf, is indicated as 412 miles, a number which is very close to 3.330 stadia of Arr. Ind. 41.8: this fact might suggest that this information derives from the Nearchean account.

${ }^{28}$ 6.97: oppidum a Nearcho conditum in navigatione et flumen Arbium navium capax, contra insula distans $L X X$ stadiis.

${ }^{29}$ Stein [1943: 214, n. 1] obtained, from Arrian's text, a different location of the mouth of the Arabis, identified with the actual Hab, which flows few miles to N-E of Ras Müari. For Stein the error depended both on the idea that the shoreline, at the time of Alexander, was more to the north, and on the absence of archaeological evidence.

${ }^{30}$ 6.107: Carmaniae oram patere duodeciens quinquaginta milia passuum Nearchus scripsit.

${ }^{31}$ 6.96: Onesicriti et Nearchi navigatio nec nomina omnia habet mansionum nec spatia, primumque Xylinepolis ab Alexandro condita, unde ceperunt exordium, iuxta quod flumen aut ubi fuerit non satis explanatur. haec tamen digna memoratu produntur ab iis.

32 6.109: Onesicritus et Nearchus ab Indo amne in sinum Persicum atque illinc Babylonem Euphratis paludibus scripserunt $|X V I I|$ esse. in Carmaniae angulo Chelonophagi, testudinum superficie casas tegentes, carne vescentes. a flumine Arabi promunturium ipsum inhabitant praeter capita toto corpore hirti coriisque piscium vestiti.

33 6.124: Euphrate navigari Babylonem e Persico mari CCCXL p. tradunt Nearchus et Onesicritus. 
I am going to omit the question of measurement and transformation of stadia into Roman miles, but I would like to focus on the following point. The quotations analyzed so far, where Onesicritus and Nearchus appear at the same time, not only represent reports about the context of the naval expedition along the coast and the subsequent report to Alexander, but sometimes they also seem to have quite precise information. In contrast to it, in $N H$, the fragments concerning only Onesicritus seem to have a very different and precisely identifiable theme.

The passage $2.183-185^{34}$ deals with the shadows on Mons Maleus. We learn that in the summer the shadows there lean to the south, while in winter they lean to the north; in addition, the Great Bear is visible only for 15 nights. During Alexander's stay — says Pliny in 2.185 — it was recorded that the Bear could only be seen in the early part of the night, while Onesicritus wrote that there are places in India where it can't be seen and that these places are called Askia. Another Plinian passage - 7.28 35 - must be linked to this last information. It's where Onesicritus is quoted regarding the characteristics of the Indians inhabiting the areas of the country without shadow: they would be tall more than five cubits, they would live for at least 130 years and they would die without knowing a real aging process. The phenomenon we are speaking about is not possible in India at the latitudes reached by the expedition, but it actually occurs in nature and it is seen starting from the Tropic of Cancer (24 latitude and $46^{\circ} 1^{\prime}$ longitude in the time of Alexander). In Onesicritus' account concerning an inland region of northern India, Pliny must have recognized a phenomenon similar to that which took place in Siene, a city of Upper Egypt, during the summer solstice. He exploited his astronomical knowledge to shape a "land of the Absurd", a utopian reality, where the same laws of nature are subverted or suspended. At $6.81^{36}$ the text talks about Taprobane and how Onesicritus tells that elephants found there are bigger and more belligerent than elephants in India.

There is little doubt that the reality described by Onesicritus, from the quotations of Strabo and Pliny, has to be identified with the island of Ceylon / Sri Lanka, and more likely it must be regarded as the first mention of this place in Western literature. What is important to us here is that the Onesicritean Taprobane was a remote reality difficult to access, a sort of "boundary of humanity", where all the characteristics of India known by the Greek-Macedonians are concentrated in amplified form. Some mirabilia also refer to the other two fragments of Onesicritus in Pliny concerning extraordinary tree species. At $12.34^{37}$ he speaks about exotic trees and thorny shrubs that grow in Gedrosia: their juice, if splashed in the eyes, blinds a person. Here also grows a grass with a strong odor: its fluid, if consumed, kills

34 2.183-184: simili modo tradunt in Syene oppido, quod est supra Alexandriam quinque milibus stadium, solstiti die medio nullam umbram iaci puteumque eius experimenti gratia factum totum inluminari.ex quo apparere tum solem illi loco supra verticem esse, quod et in India supra flumen Hypasim fieri tempore eodem Onesicritus scribit.

35 7.28: Onesicritus, quibus locis Indiae umbrae non sint, corpora hominum cubitorum quinum et binorum palmorum existere, et vivere annos CXXX nec senescere, sed ut medio aevo mori.

${ }^{36}$ 6.81: Taprobanen alterum orbem terrarum esse diu existimatum est Antichthonum appellatione. ut insulam liqueret esse Alexandri Magni aetas resque praestitere. Onesicritus classis eius praefectus elephantos ibi maiores bellicosioresque quam in India gigni scripsit.

${ }^{37}$ 12.34: Onesicritus tradit in Hyrcaniae convallibus fico similes esse arbores quae vocentur occhi, ex quibus defluat mel horis matutinis duabus. 
instantly. Onesicritus says that in Hyrcania - south Caspian valley - there are fig-like trees called "Eyes", from which honey runs for two hours in the morning. Hyrcanian trees, whose figs that are much sweeter and more productive than ours, are mentioned at $15.68^{38}$ as well as at 12.34. It seems clear therefore that Pliny, in his selection of the Onesicritean fragments, was more interested in extraordinary phenomena than in information that was more related to the voyage from India to Babylon and most likely drawn from Nearchus. In conclusion, for the geography of Africa, Arabia and India Pliny seems to draw from Isidorus of Charax ${ }^{39}$ but, above all, from Juba, who lived in the Augustan Age and died in $23 \mathrm{CE}$, at about the same time as Strabo. Above all we owe him the information about the way to India, about the course of the Euphrates between Babylon and Charax (6.124) and about the south coast of Arabia (6.149) as well as the fauna of the southern areas, the subtropical trees and the treasures of Arabia, pearls and other gemstones.

For a complete overview see the summary table.

\begin{tabular}{|c|c|c|}
\hline & VI Book NH & Naturalis Historia \\
\hline Diognetus & $\underline{61}$ & 1 (Indices 6.12.13) \\
\hline Baeton & $\underline{61}, 69$ & 1 (Indices 5.6.7), 7.12 \\
\hline Ptolemaeus I & - & $\begin{array}{c}1 \text { (Indices } 12.13) \\
7.123,7.208,35.89\end{array}$ \\
\hline Aristobulus & - & - \\
\hline Nearchus & $\underline{96}, 97,107, \underline{109}, \underline{124}$ & 1 (Indices 6.12.13) \\
\hline Onesicritus & $81, \underline{96}, \underline{109}, \underline{124}$ & $\begin{array}{c}1 \text { (Indices 2.6.7.10.12.13.14.15), 2.183 } \\
2.185,7.28,12.34,15.68\end{array}$ \\
\hline Iuba & $\begin{array}{c}96,124,139,141,149,156 \\
170,175,176,179,201 \\
203,205\end{array}$ & $\begin{array}{c}1 \text { (Indices 5.6.8.9.19.12.13.15.25.31.32. } \\
33.35 .36 .37), 5.165 .20,5.51,5.59,8.7, \\
\text { 8.14, 8.35, 8.48, 8.107, 8.156, 9.115, } \\
\text { 10.126, 12.39, 12.56, 12.61, 12.67, } \\
\text { 12.80, 13.34, 13.92, 13.142, 15.99, } \\
25.14,25.77-78,31.18,32.10,33.118, \\
35.39,36.163,37.24,37.69,37.73 .\end{array}$ \\
\hline
\end{tabular}

Everything I have addressed so far is likely derived from Juba's De expeditione arabica $\left(6.141,12.56\right.$ and 32.10) and from other works of geography about Africa ${ }^{40}$ and India, such as the lost work of Seneca De situ Indiae.

Roman military news and military reports in general seem less important, as we do not know how much they may have influenced the improvement of the information available.

38 15.6.8: Onesicritus tradit in Hyrcania multum nostris esse dulciores fertilioresque (sc. ficos), ut quae modios CCLXX singulae ferant.

${ }^{39}$ Isidorus of Carax wrote two minor literary works: the first one on pearls in the Persian Gulf, and the second one on the way from Zeugma to Alexandria: he was sent to the East by Augustus before his adopted son Caius Caesar died in 4 CE. FGrHist 781; BNJ 781; [Schoff 1914; Walser 1985; Chaumont 1984; Khlopin 1977].

${ }^{40}$ See [Hönigmann 1926, very important 178]. 
Juba is the only Greek author, probably used directly and for large sections by Pliny, while others - Ephorus, Timaeus, Polybius, Eratosthenes - had rarely been used directly and much more likely he did it through paradoxographic collections. However, Sallmann [1971: 85-88] affirms that, even if Pliny could not have consulted Juba's work about Arabia, he would certainly have been able to use directly other works of the king of Mauretania, because Pliny had knowledge of Juba's entire work, which he praised at 5.16.

Pliny thus proves to know the work of the bematists but completely ignores the historiographical work of Aristobulus and mentions Ptolemaeus only in specific dossiers regarding certain subjects. Considering Onesicritus, the Naturalist declares that he draws his account from Juba - 6.96 - but in relation to the passages analyzed here it seems that Pliny consistently took inspiration from the work of Nearchus, especially regarding the data about navigation.

Onesicritus remains the main source for data related mostly to mirabilia, but not for information related to the knowledge about the coast from India to Babylon. The Naturalist used therefore specific dossiers on different subjects, but the common trait is that it did not prove him to have ever had a true historical interest either in the expedition of Alexander or what it meant.

Pliny makes sporadic notes about the contemporary historians of Alexander and let us suppose their lesser importance for his work. Moreover, in the contemporary political life of the Plinian age historiography was not a very neutral refuge (in other words it wasn't something very advisable to do), especially during the last years of Nero's reign.

The passages concerning the historians of Alexander don't have as significant role, as they will in Arrian's Anabasis: the Nicomedian historian thinks that the achievements of Alexander the Great as Res Gestae should be used as exemplum for Trajan ${ }^{41}$, while Pliny doesn't want and cannot "show as exemplum" anything to emperors Vespasian or Titus.

The encyclopedic purpose of the work has strongly conditioned the content: "the inventory of the World of the Flavian age" was no longer interested and fascinated by the myth of Alexander, which instead had been the reference point of the Imitatio Alexandri of Augustean propaganda [Cresci Marrone 1993: 15-30].

\section{References}

Aly, F. (1882). Die Quellen des Plinius in achten Buch der Naturgeschichte. Marburg:

N. G. Elwert. (In German).

Berger, E. H. (1903). Diognetos (16). In A. Pauly, G. Wissowa, W. Kroll, et al. (Eds.). Paulys Realencyclopädie der classischen Altertumswissenschaft (Vol. 5.1), 785. Stuttgart:

J. B. Metzler Verlag (In German).

Berve, H. (1926). Das Alexanderreich Auf Prosopographischer Grundlage (Vol. 2). München: Beck. (In German).

Bosworth, A. B. (1980). A historical commentary on Arrian's History of Alexander, (Vol. 1) Commentary on Books I-III. Oxford: Clarendon Press.

${ }^{41}$ See [Sisti 2001: xx, n. 1] with a good selection of bibliography about the influence of Alexander in the Hellenistic age and in the Roman world. 
Bosworth, A. B. (1988). From Arrian to Alexander: Studies in historical interpretation. Oxford: Clarendon Press.

Brieger, A. (1857). De fontibus librorum XXXIII, XXXIV, XXXV, XXXVI, Naturalis historiae Plinianae, quatenus ad artem plasticam pertinent (Diss). Greifswald. (In Latin).

Brown, T. S. (1949). Onesicritus: A study in Hellenistic historiography. Berkeley: Univ. of California Press.

Brunn, H. (1856). De auctorum indicibus Plinianis disputatio isagogica. Bonnae: Litteris Caroli Georgi. (In Latin).

Brunt, P. A. (1974). Notes on Aristobulus of Cassandria. The Classical Quarterly, 24(1), 65-69.

Brunt, P. A. (Ed.) (1983). Arrian, History of Alexander and Indica. Cambridge, Mass.: Harvard Univ. Press.

Bucciantini, V., (2013). Misurazioni e distanze marittime nel Periplo di Nearco. In K. Geus, M. Rathmann (Eds.). Vermessung der Oikoumene: Mapping the Oikumene, 65-76. Berlin: De Gruyter. (In Italian).

Bucciantini, V., (2015). Studio su Nearco di Creta. Dalla geografia descrittiva alla narrazione storica (Studi di Storia Greca e Romana, n. 11). Alessandria: Edizioni dell'Orso. (In Italian).

Chaumont, M.-L. (1984). Études d'histoire parthe. V: La route royale des Parthes de Zeugma à Séleucie du Tigre d'après l'itinéraire d'Isidore de Charax. Syria, 61(1), 63-107. (In French).

Conte, G. B. (1982). Introduzione. In Gaio Plinio Secondo, Storia Naturale. Vol. 1. Cosmologia e geografia. Torino: Einaudi. (In Italian).

Cotta Ramosino, L. (2001). La guerra e lo sviluppo delle conoscenze geografiche in Plinio: tra condanna e valorizzazione. In M. Sordi (Ed.). Il pensiero sulla guerra nel mondo antico, 209-223. Milano: Vita e Pensiero. (In Italian).

Cresci Marrone, G. (1993). Ecumene Augustea. Una politica per il consenso. Roma: L'Erma di Bretschneider. (In Italian).

Dalstein, J. (1885). Quibus fontibus Plinius in artificum historia usus sit (Diss.). Metz. (In Latin).

De Romanis, F. (1992). Viaggi ed esplorazioni oltre i confini dell'Impero fra l'età di Plinio e quella di Tolomeo. In G. Aujac. O. Baldacci, P. Barozzi (Eds.). Optima Hereditas. Sapienza giuridica romana e conoscenza dell'ecumene, 267-274. Milano: Libri Scheiwiller. (In Italian).

Della Corte, F. (1954). App. II. La nuova lex Brunn sugli indici di Plinio. In F. Della Corte. Varrone, il terzo gran lume romano, 283-319. Genova: Pubblicazioni dell'Istituto Universitario di Magistero. (In Italian).

Detlefsen, D. (1909). Die Anordnung der geographischen Bücher des Plinius und ihre Quellen. Berlin: Weidmann. (In German).

Geier, R. (1844). Alexandri Magni historiarum scriptores aetate suppares. Leipzig: Gebauer. (In Latin).

Heckel, W. (2006). Who's who in the age of Alexander the Great. Oxford: Blackwell.

Hönigmann, E. (1926). Libye. In A. Pauly, G. Wissowa, W. Kroll, et al. (Eds.). Paulys Realencyclopädie der classischen Altertumswissenschaft, (Vol. 13), 149-202. Stuttgart: J. B. Metzler Verlag (In German).

Howe, T. (2018) Ptolemy I Soter: A self-made man. Oxford: Oxbow Books.

Jacoby, F. (Ed.) (1926-1930). Die Fragmente der griechischen Historiker, (Vol. 2) B: Spezialgeschichten, Autobiographien und Memoiren, Zeittafeln [nn. 106-261]. Berlin: Weidmann. (In German).

Jacoby, F. (Ed.) (1930). Die Fragmente der griechischen Historiker, (Vol. 2) D: Kommentar zu Nr. 106-261. Berlin: Weidemann. (In German).

Janni, P. (1978). "Il Sole a Destra": Estrapolazione nella Letteratura Geografica Antica e nei Resoconti di Viaggio. Studi Classici e Orientali, 28, 87-115. (In Italian). 
Janni, P. (1996). Il mare degli antichi. Bari: Dedalo. (In Italian).

Janni, P. (2004). Miti e falsi miti. Luoghi comuni, leggende, errori sui Greci e sui Romani. Bari: Dedalo. (In Italian).

Khlopin, I. (1977). Die Reiseroute Isidors von Charax und die oberen Satrapien Parthiens. Iranica Antiqua, 12, 117-165. (In German).

Kirwan, L. P. (1957). Rome beyond the southern Egyptian frontier. The Geographical Journal, 123(1), 13-19.

Klotz, A. (1906). Quaestiones Plinianae geographicae (Quellen und Forschungen zur alten Geschichte und Geographie, 11). Berlin: Weidmann. (In German).

Klotz, A. (1907). Die Arbeitsweise des Älteren Plinius und die Indices Auctorum. Hermes, 42, 323-329. (In German).

Le Bonniec, H. (1946). Bibliographie de l'Histoire naturelle de Pline l'Ancien. Paris: Les Belles Lettres. (In French).

Matthews, V. J. (1974). The "Hemerodromoi": Ultra long-distance running in Antiquity. Classical World, 68(3), 161-169.

Meredith, D. (1953). Annius Plocamus: Two inscriptions from the Berenice road. Journal of Roman Studies, 43, 38-40.

Moretti, A. (2012). Introduzione ad Aristobulo. In V. Costa (Ed.). Tradizione e trasmissione degli storici greci frammentari II. Atti del III Workshop Internazionale, Roma, 24-26 febbraio 2011, 211-235. Tivoli: Edizioni Tored. (In Italian).

Moretti, A. (2013). Aristobulo e Curzio Rufo: alcuni confronti. In F. Gazzano, G. Ottone (Eds.). Le età della trasmissione. Alessandria, Roma, Bisanzio. Atti delle giornate di studio sulla storiografia greca frammentaria (Genova, 29-30 maggio 2012), 251-270. Tivoli: Edizioni Tored. (In Italian).

Münzer, F. (1897). Beiträge zur Quellenkritik der Naturgeschichte des Plinius. Berlin: Weidmann. (In German).

Pearson, L. (1952). Aristobulus the Phocian. American Journal of Philology, 73, 71-75.

Pearson, L. (1960). The lost histories of Alexander the Great (Philological Monographs; 20). New York: The American Philolological Asssociation.

Pédech, P. (1984). Historiens, Compagnons d'Alexandre. Paris: Les Belles Lettres. (In French).

Primo, A. (2009). La storiografia sui Seleucidi: da Megastene a Eusebio di Cesarea. Pisa: Fabrizio del Serra Editore. (In Italian).

Rabenhorst, M. (1907). Der Ältere Plinius als Epitomator des Verrius Flaccus. Ein Quellenanalyse des Siebenten Buches der Naturgeschichte. Berlin: Georg Reimer. (In German).

Roller, D. W. (2003). The world of Juba II and Kleopatra Selene: Royal scholarship on Rome's African frontier. London: Routledge.

Sallmann, K. G. (1971). Die Geographie des älteren Plinius in ihrem Verhältnis zu Varro. Berlin,: De Gruyter. (In German).

Schiwek, H. (1962). Der Persische Golf als Schiffahrts und Seehandelsroute in Achämenidischer Zeit und in der Zeit Alexander des Großen. Bonner Jahrbücher, 162, 4-96. (In German).

Schoff, W. H. (Ed.) (1914) Parthian Stations. By Isidore of Charax: An account of the overland trade route between the Levant and India in the first century B.C.: The Greek text, with a translation and commentary. Philadelphia: The Commercial Museum.

Schwartz, E. (1896). Baiton. In A. Pauly, G. Wissowa, W. Kroll, et al. (Eds.). Paulys Realencyclopädie der classischen Altertumswissenschaft (Vol. 2.2), 2779. Stuttgart: J. B. Metzler Verlag. (In German).

Schwartz, E. (1897). Bematistai. In A. Pauly, G. Wissowa, W. Kroll, et al. (Eds.). Paulys Realencyclopädie der classischen Altertumswissenschaft (Vol. 3), 266-267. Stuttgart: J. B. Metzler Verlag. (In German). 
Sisti, F. (Ed.) (2001). Arriano. Anabasi di Alessandro I (Libri I-III). Milano: Mondadori. (In Italian).

Sprengler, J. G. (1891). Die Quellen des älteren Plinius in 12. und 13. Buch der Naturgeschichte. Rheinische Museum für Philologie, 46, 54-70. (In German).

Stadler, H. (1891). Die Quelle des Plinius im 19. Buche der Naturalis Historia. Neuburg a D.: Griessmayersche Buchdruckerei. (In German).

Stein, A. (1943). On Alexander's route into Gedrosia: An archaeological tour in Las Bela. The Geographical Journal, 102, 193-227.

Tonnet, H. (1988). Recherches sur Arrien, sa personalité et ses écrits atticistes (2 Vols.). Amsterdam: Hakkert. (In French).

Tzifopoulos, Y. Z. (1998). 'Hemerodromoi' and Cretan 'dromeis': Athletes or military personnel? The case of the Cretan Philonides. Nikephoros, 11, 137-170.

Tzifopoulos, Y. Z. (2013). Bematists. In R. S. Bagnall et al. (Eds.) The encyclopedia of ancient history (Vol. 2), 1079-1080. Malden, MA: Wiley-Blackwell. https://doi. org/10.1002/9781444338386.wbeah09247.

Walser, G. (1985). Die Route des Isidorus von Charax durch Iran. Archäologische Mitteilungen aus Iran. 18, 145-156. (In German).

Wirth, G. (1959). Ptolemaios als Schriftsteller und Historiker. In A. Pauly, G. Wissowa, W. Kroll, et al. (Eds.). Paulys Realencyclopädie der classischen Altertumswissenschaft (Vol. 23), 2467-2484. Stuttgart: J. B. Metzler Verlag. (In German).

Worthington, I. (2016). Ptolemy I: King and Pharaoh of Egypt. Oxford: Oxford Univ. Press.

$$
* * *
$$

\section{Информация об авторе}

\section{Вероника Буччантини}

$\mathrm{PhD}$

nрофессор,

факультет литературы и философии

(Dipartimento di Lettere e Filosofia, DILEF),

Флорентийский университет

(Università degli Studi di Firenze)

Via della Pergola 6050121 Firenze

Тел.: +39 (055) 2757891

veronica.bucciantini@unifi.it

\section{Information about the author}

\section{Veronica Bucciantini}

$\mathrm{PhD}$

Professor,

Department of Letters and Philosophy,

University of Florence

Via della Pergola 6050121 Firenze

Tel.: +39 (055) 2757891

veronica.bucciantini@unifi.it 